\title{
Design Strategy Model for Sustainable Spacial Planning
}

\author{
Sooknyung Ha \\ College of Design, Sangmyung Univ., Cheonan-si, Chungcheongnam-do, South \\ Korea \\ snha3430@smu.ac.kr
}

\begin{abstract}
The purpose of this study was to explore the methods and strategies for sustainable materials to be provided to the design industry, along with the responsibility for managing the usable alternative resources as a means to recognize and cope with the seriousness of global environmental problems. Space Re-Design is based on the respect towards humanity and nature and highlights the social responsibility to be fulfilled by the design, taking the 3 pillars of sustainable design, i.e., social value, environmental value, and economic value into consideration.

Space Re-Design refers to the design that is completed by reprocessing and rearranging the already used or discarded materials, not new materials such as all articles and finishing materials, necessary to re-plan the design in such a way that suits new purpose, although most portion of original space is preserved. In other words, Space Re-Design requires the methods and strategies promoting the circulatory use of materials from the aspect of comprehensive and systematic supply of materials which are recycled only through primary processing such as hitting, cutting, and folding, instead of applying heat to make new goods or products.

For that, this study is meaningful in that it explored the circulatory model of materials necessary to plan and create the new sustainable space based on consideration of design history related to the tangible/intangible value of sustainable design and difference and repetition.
\end{abstract}

Keywords: Strategy, Model, Sustainable, Spacial, Re Design

\section{Introduction}

Recently, the resource circulation society has been thrust into limelight in environment sector. The Ministry of Environment set a goal of creating a resource circulation society that goes beyond waste recycling and reuses resources and energy rather than discarding them. In other words, the Ministry intends to build a resource-circulating sustainable country with virtuous cycle of resources. Although the measures for recycling that requires energy are constantly developed, there is very little study on recycling. Therefore, this study intended to lay foundation for promoting the sustainable space by taking an approach from the perspective of reuse which would involve the circulation and reuse of original materials. For that, we intend to conduct this study as a basic research for developing the design strategy model necessary to plan and create sustainable space through review of literatures related to sustainability design and web information search.

Article history:

Received (February 28, 2019), Review Result (April 24, 2019), Accepted (June 19, 2019) 


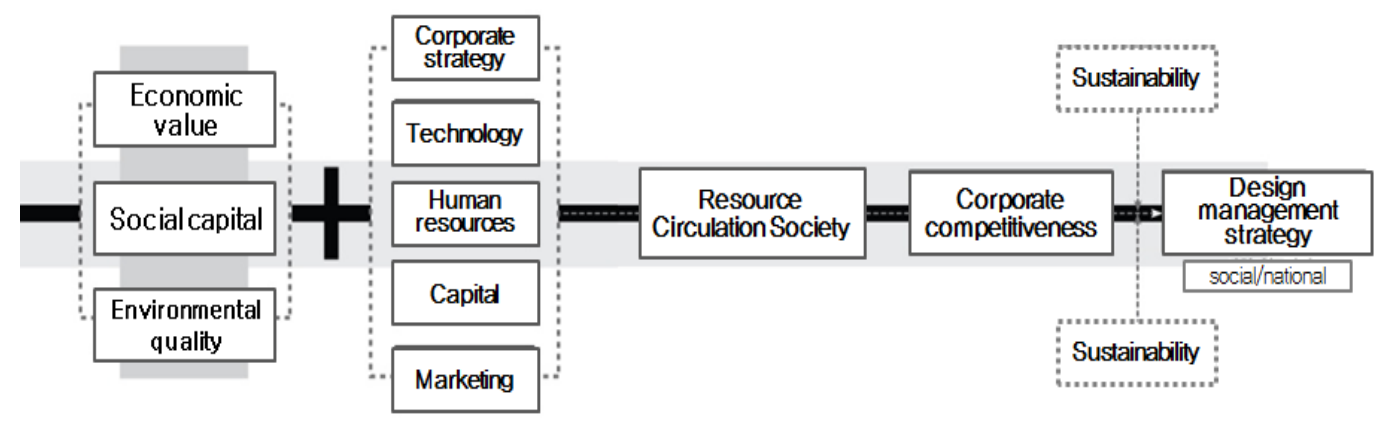

Figure. 1 A goal of creating a resource circulation society

\section{Sustainable Reuse Design}

As mentioned above, the TBLD and Sustainability2.0 have slight difference in the area of their applications in terms of design strategy and brand strategy. However, TBLD and Sustainability2.0 can be applied strategically when they are based on sustainable design, and in that regard, we intended to examine their strategic applicability by putting both concept models into relevant case.

As an alternative to resolve the environmental problems caused by the technological civilization-oriented industrial society, it has been strongly recommended that the products should be sustainable without any adverse effect on the environment or should be reused even at the end of life for other purposes. There is a variety of design terms related to preservation of the environment. For example, there are green design, eco design, environment-friendly design, recyclable design, and reuse design. However, even these terms are used almost in an intermixed manner, and most of the reuse designs that we intend to focus on in this study are covered and simply addressed by aforesaid terms[2].

Therefore, it is necessary to map out the methods and strategies that can be easily recognized and applied as the measures for approach from a comprehensive and systematic aspect of supply of sustainable materials. This is because large quantities of materials and products, which are stocked without being used or are disposed of due to overproduction in industrialized society, have the advantage that they can be directly tapped into for reuse without undergoing the process of recycling[3].

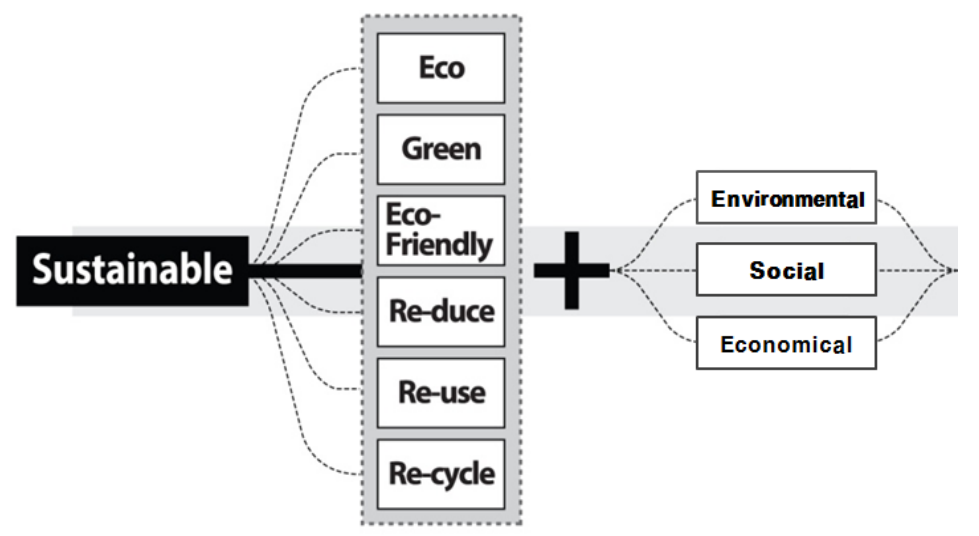

Figure. 2 Comprehensive Concept of Sustainable Design 
Table 1. Reused Design Cases

\begin{tabular}{c|l|c|l}
\hline \multicolumn{1}{c|}{ Image } & \multicolumn{1}{|c|}{ Title } & Image & \multicolumn{1}{c}{ Title } \\
\hline & $\begin{array}{l}\text { Cans repurposed as a } \\
\text { chair in Brazil }\end{array}$ & $\begin{array}{l}\text { Plastic Bottles and LED Lights } \\
\text { repurposed as a chandelier } \\
\text { during Ramadan in Muslim } \\
\text { Quarter, Jerusalem }\end{array}$ \\
\hline & $\begin{array}{l}\text { Eletrice wire reel } \\
\text { reused in like a } \\
\text { furniture eco-design }\end{array}$ & $\begin{array}{l}\text { Railroad Ties repurposed as a } \\
\text { driveway in Brazil }\end{array}$ \\
\hline $\begin{array}{l}\text { Jacobsen House } \\
\text { Bathroom Earthship }\end{array}$ & & Skis repurposed as a bench \\
\hline
\end{tabular}

\section{Sustainability of Spaces Based on Tangible/Intangible Concept of Design and Difference and Repetition}

\subsection{Tangible/Intangible Concept and Value of Sustainability}

In a book titled “Old Future' written by Helena Norberg Hodge(1996), she described the lives of people who led sustainable and circulatory self-reliant lives even in the barren natural environment, accepted the life and death, and felt deep happiness while she was living with the indigenous people for 2 decades in a desolate small village called Ladakh in Tibet on the plateau of the West Himalayas[1]. 'Silent Spring', authored by Rachel Carsons (1962) has formed the basis for social movement advocating the types of consumption which is based on opposite values and social development and environmental protection, i.e., the commitment to responsible consumption, in conjunction with the spread of consumerism model[2]. Andreas Weber(2009) advises that the growth-oriented economy, fraught with problems such as the distribution of wealth and environmental destruction, will bring disaster, while the economic activity reflecting the right value of the nature will lead to constant economic activities and even happiness.

In addition, William McDonough \& Michael Braungart(2002) also stated in the 'Cradle to Cradle' that a new consumption system should be built to allow the consumed resources to be transformed into second resource for production in the next stages, rather than being thrown away[3].

Table 2. Summary of Tangible/Intangible Concept and Value of Sustainability

\begin{tabular}{c|c|c}
\hline Authors(Year) & Books & Summary of Concept and Value \\
\hline $\begin{array}{c}\text { Helena Norberg } \\
\text { Hodge (1996) }\end{array}$ & $\begin{array}{c}\text { Ancient Futures : } \\
\text { Learning from } \\
\text { Ladakh }\end{array}$ & $\begin{array}{c}\text { Cultural Identity/Ecological } \\
\text { Preservation/ Self-sufficiency }\end{array}$ \\
\hline Jason & Philosophy of & Redesign of place and system/Sense of \\
McLennan(2009) & Sustainable Design & $\begin{array}{c}\text { Responsibility/ Preservation of Natural } \\
\text { Environment[4] }\end{array}$ \\
\hline
\end{tabular}




\begin{tabular}{c|c|c}
\hline $\begin{array}{c}\text { Rachel Carsons } \\
(2002)\end{array}$ & Silent Spring & $\begin{array}{c}\text { Value Creation/Social } \\
\text { Development/Environmental } \\
\text { Protection/Responsible Consumption }\end{array}$ \\
\hline $\begin{array}{c}\text { Andreas Weber } \\
(2009)\end{array}$ & $\begin{array}{c}\text { The Nature is the } \\
\text { Economy }\end{array}$ & $\begin{array}{c}\text { Earth Community/Economic Efficiency } \\
\text { and Natural Conservation/Economic } \\
\text { Model/Value of the Nature }\end{array}$ \\
\hline $\begin{array}{c}\text { William McDonough } \\
\text { \& Michael Braungart } \\
(2002)\end{array}$ & Cradle to Cradle & $\begin{array}{c}\text { Infinite Reproduction/New } \\
\text { production/Establishment of } \\
\text { Consumption System/Circulatory } \\
\text { Resources }\end{array}$ \\
\hline
\end{tabular}

\subsection{Creation of Design Value Based on Difference and Repetition}

The concept of repetition has been addressed intensively in the fields of philosophy and the art. Close look at all things making up the world shows that they consist of repetitive combination of very tiny units. Repeated combination of unit cells, ranging from inorganic materials such as air, soil, and rocks to organisms such as trees, plants and animals, determines the characteristics. There are various discussions on the repetition, in addition to the repetition by such physical structure. The concept of repetition has many implications both artistically and philosophically[5].

However, the repeatability in space cannot be explained simply based on the concept of art or philosophy. Thus, we analyzed the repeatability first in the field of philosophy and art in order to examine the repeatability that could be found in the space. In the case of philosophy, the repetition is closely related to the existence based on the perspective of Gilles Deleuze and 'difference and repetition' written by him. He considered that repetition and replication did not blur out the existence but rather reinforced the existence due to difference between repetitions. Since then, ready-made, invented by Duchamp, has become a strategy for later artists to express their new artistic values through the reproduction and repeatability of objects. Minimalism and pop art are the most typical examples. What was intended by the minimalists could eventually be achieved through arrangement rather than configuration or composition. This method of repetition and continuation has the characteristic of expandability that causes the art works and audience to be present in the same space, inducing the spatial experience that maintains close relationship with the audience. Space is also made up of many different members that are combined. Particularly, the materials that surround the space are often attached and connected repeatedly based on single unit [6].

The tendency to use the same material repeatedly in the exterior surface of space can be found to be related to minimalism. That reflects their pursuit of rationality, and furthermore, explains the purpose of design through certain arrangement and placement[7]. 


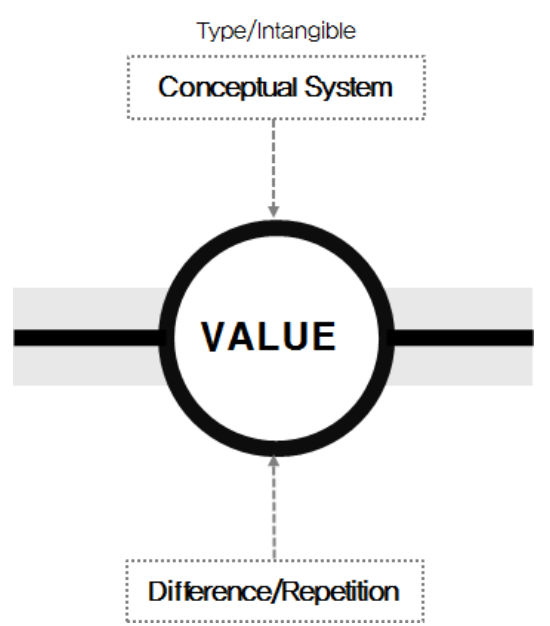

Figure. 3 Design Value Based on Difference and Repetition

As mentioned above, we examined the value through the prism of philosophical concept and design history concept which arose from repetition and difference. The choice of materials plays an important role in planning the sustainable space. In particular, the creation of space where materials are reused would definitely represent the design that is very valuable and stands out. Thus, strategies and methods, which allow those materials to be used repeatedly and easily accessible, should be explored [8].

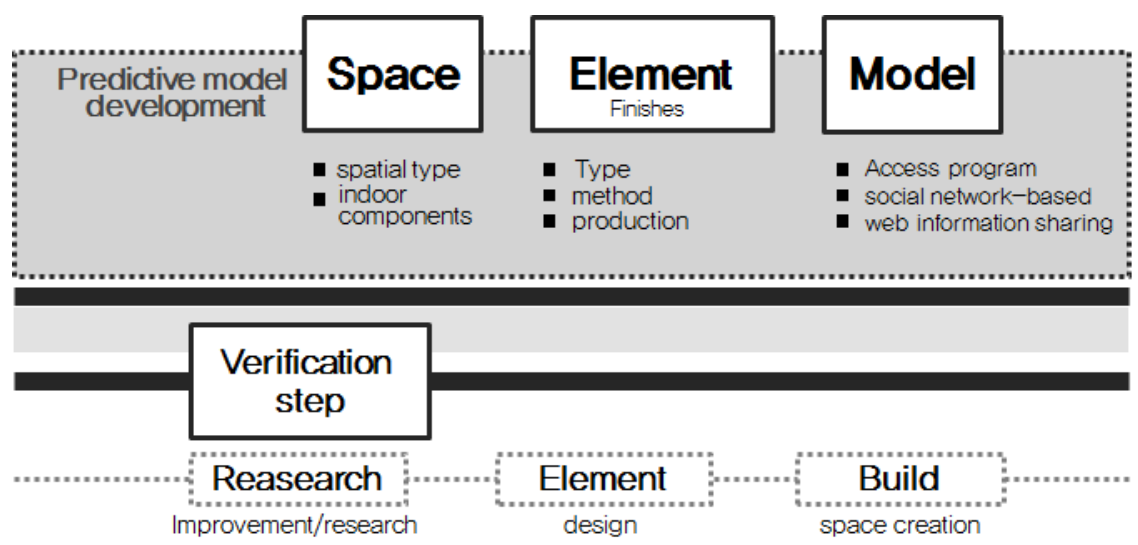

Figure. 4 Predictive Model for Sustainable Space Creation

\section{Conclusions}

Recent trend of space in Korea shows that even useless resources become valuable resources for someone. Furthermore, waste is no longer a waste, but is transformed into new resource. Thus, it would be necessary to provide an opportunity toturn the waste resources into valuable resources for other people based on efficient marketing elements of waste resources by changing the paradigm of transaction of pre-owned goods and waste recycling across the country. Along with that, we should take the lead in promoting the exchange of information between the suppliers and users of waste resources and minimizing the disposal of resources in conjunction with the on/off-line systems of waste resources. In particular, it would benecessary 
to promote smooth communication and legalization of waste transaction actively by integrating the junk shop nationwide, which play key roles in the on/off-line resource circulation process of waste resources, into the mainstream system. Future design may be the act of making the design more important, rather than creating better designs.

\section{References}

[1] H. N. Hodge, Helena Norberg Hodge, Sierra Club Books, (1992)

[2] R. Carson, Silent Spring, Houghton Mifflin, (2002)

[3] W. McDonough and M. Braungart., Cradle to Cradle, North Point Press, (2002)

[4] J. F. McLennan, The Philosophy of Sustainable Design, Ecotone Publishing Company, (2004)

[5] Ha. S, and Lee. J. Reuse of design strategies on case study of 2012Architecten, Journal of Korean Society of Design Science. (2013), Vol.26, No.1, pp.383-402.

[6] S. Kang, Korean institute of interior design, 5, 12 (2003)

[7] S. N. Ha and J. G. Lee, Journal of Korean Society of Design Science, 1, 26 (2013), pp.383-402

[8] Y. Lee, Y. M. Lee and S. Ha, The Korean Society of Living Environmental System, 3, 11 (2004) 